\title{
Ontologiczne podstawy edukacji religijnej w chrześcijaństwie
}

\section{KEY WORDS}

person, the religious education, the religious pedagogics, essential aspect of the person, existential aspect of the person, formation, conffesional education, conscience

\begin{abstract}
Wysocki Adam, Ontologiczne podstawy edukacji religijnej w chrześcijaństwie [Ontological Bases of the Religious Education in Christianity]. Kultura - Społeczeństwo - Edukacja nr 1(7), 2015, Poznań 2015, pp. 135-148, Adam Mickiewicz University Press. ISBN 978-83-232-2944-5. ISSN 2300-0422
\end{abstract}

The article indicates ontological bases which are at the ground of the religious education in Christianity. The touched problem considers issues of Christian anthropology and concerns the category of the person. The definite concept of the man forejudges applied pedagogic manners, that is the way of the approach to the pupil. The characteristics of the person indicates that for purposes of efforts of the man is his salvation, that in Christianity is the achievement of Communion with God, therefore the Christian religious education in its message points soteriological goals and measures. However nowadays, pluralism and multiculturalism and conditions of the public school extort using such type of the religious education which on one hand will accomplish ontological premises of Christian anthropology and on the other hand requirements of the present day.

Jeśli przyjrzymy się podstawowym pojęciom z zakresu pedagogiki ogólnej, to na plan pierwszy wysuwają się zagadnienia związane z edukacją, wychowaniem i kształceniem. Leon Zarzecki wskazuje, że stanowią one przedmiot pedagogiki jako dziedziny naukowej, a na pewnym poziomie ogólności są to pojęcia bliskoznaczne, które oznaczają pewien sposób oddziaływania wspierający warunki oraz procesy służące rozwojowi jednostki tak, by mogła osiągnąć pełnię swoich możliwości oraz być zdolna do przejawiania postaw aktywności na rzecz dobra wspólnego całego społeczeństwa (Zarzecki, 2012: 7). Autor, precyzując wymienione pojęcia, stwierdza, że edukacja ma najszerszy zakres znaczeniowy, który dotyczy tego typu oddziaływań prowadzących do formowania, a więc zmiany 
i rozwoju zdolności życiowych człowieka w obszarze emocjonalnym, intelektualnym, motywacyjnym oraz interpersonalnym (Zarzecki, 2012: 11-12). Sama pedagogika chrześcijańska wpisuje się w nieco szerszy nurt - pedagogiki religijnej (Marek, 2013: 102-103). Każda teoria pedagogiczna, formułując swoje twierdzenia, ma na uwadze określoną teorię człowieka, stąd rozważania tu podjęte dotyczą antropologii chrześcijańskiej i ukazują ontyczną strukturę człowieka.

Pedagogika chrześcijańska na gruncie katolicyzmu ma charakter chrystocentryczny i odwołuje się do moralności chrześcijańskiej, personalizmu i humanizmu chrześcijańskiego. Moralność chrześcijańska głosi zasady ewangeliczne naśladowania życia Jezusa i upodabniania się do Niego, wskazuje na gotowość do miłości i ofiary wobec wszystkich, a szczególnie tych najbardziej potrzebujących. Założenia wychowawcze mają przede wszystkim na uwadze rozwijanie ducha Chrystusowego oznaczające dążenie do dobra z jednoczesnym unikaniem zła, oraz aktywność apostolską wraz z miłosierdziem i współczuciem. Te idee wychowawcze mają na celu przeobrażenie człowieka $\mathrm{z}$ naturalnego nastawienia egoistycznego oraz rozwój jego najlepszych cech. Pedagogika chrześcijańska według Stefana Kunowskiego opiera się na założeniach teizmu, akcentuje stosunek osobowy człowieka do Boga, w którym prawdy objawione w postaci dogmatów są wyznacznikiem dla aktywności człowieka. Z tego względu pedagogika chrześcijańska przede wszystkim ma charakter teo-Chrysto-eklezjocentryczny (Kunowski, 2004: 95). Rozumową podstawę dla niej stanowi filozofia realizmu arystotelesowsko-tomistycznego, w której główną rolę odgrywają poglądy Tomasza z Akwinu. Kunowski wskazuje, że konsekwencją tomizmu było przyjęcie dwóch podstawowych przesłanek:

Z założeń filozoficznych tomizmu najważniejsze dla wychowania w systemie chrześcijańskim są: $1^{\circ}$ - realistyczna teoria poznania i możliwości u człowieka obiektywnego i prawdziwego poznawania całego świata na drodze wrażeń zmysłowych i abstrakcji umysłowej, czyli odkrywania cech istotnych dla tworzenia pojęć, co wyjaśnia proces nauczania konieczny dla rozwijania rozumu człowieka, oraz $2^{\circ}$ - odróżnienie w rzeczywistości dwu porządków: istoty rzeczy i ich istnienia, przy czym porządek istotowy, czyli esencjalny, stanowi - jako pełnia natury przysługującej danej rzeczy - ideał, do którego urzeczywistnienia rzecz zdąża, natomiast porządek istnieniowy, czyli egzystencjalny, tworzy stan rzeczywistego istnienia, przez które rzecz w procesie rozwojowym przechodzi aż do osiągnięcia pełni swej natury jako celu (entelechia). (Kunowski, 2004: 95)

Cytowany autor zauważa, że jest to proces podlegający dynamicznym zmianom, w którym każdy byt stworzony, zgodnie z tym, czym jest, przechodzi od potencji, czyli czystej możności, do aktu jako swojej realizacji, kształtując w określonym czasie przyporządkowaną sobie materię (Kunowski, 2004: 95). Z wymienionych podstawowych założeń wynikają pewne obszary, w których lokuje się 
całokształt przedsięwziętych zabiegów pedagogicznych. Autor, mając na uwadze przesłanie o rozwoju cielesno-duchowym, wskazuje, że obszary te stanowią współdziałanie pięciu przyczyn, które stanowią przestrzeń do działań pedagogicznych. Możemy mówić o następujących przyczynach:

- materialnej, jako cielesno-duchowe podłoże dla oddziaływań pedagogicznych;

- formalnej, która stanowi treść wychowawczą dla rozwoju fizycznego, umysłowego, społecznego, moralnego i duchowego;

- celowej, ujawniającej kierunek rozwoju, który wynika z natury ludzkiej;

- sprawczej, która dotyczy wykonawców czynności pedagogicznych, czyli nauczycieli i opiekunów;

- wzorczej, wskazującej na przykłady z historii dopomagające w realizacji założonych celów (Kunowski, 2004: 95-96).

$\mathrm{Z}$ perspektywy kwestii tu podjętych największe znaczenie ma przyczyna pierwsza, z której pozostałe bezpośrednio wynikają lub przynajmniej do której pośrednio nawiązują. Przyczyna materialna bowiem odnosi się wprost do człowieka i stanowi podstawę do formułowania celów oraz nakreślania drogi zmierzania do nich. Z tego względu punktem wyjścia jest byt ludzki, który na gruncie chrześcijaństwa stanowi kategoria osoby. Korzystając z charakterystyki dokonanej przez Wincentego Granata, możemy stwierdzić, że:

Osoba ludzka jest to jednostkowy, indywidualny, substancjalny, cielesno-duchowy podmiot zdolny działać w sposób rozumny, dobrowolny, moralny i społeczny, w celu harmonijnego ubogacania siebie i innych ludzi w zakresie kultury. (Granat, 1985: 69-70)

Osobie zazwyczaj przysługuje zestaw cech, które określają ją samą oraz w stosunku do innych osób. Antoni Podsiad wymienia następujące cechy:

a) zdolność do intelektualnego poznania, b) zdolność do miłości, c) wolność, d) podmiotowość wobec praw, e) godność, f) zupełność. Trzy pierwsze cechy (a, b, c) podkreślają rozumną naturę osoby charakteryzującą jej odrębność i transcendentność w stosunku do całej natury; trzy następne (d, e, f) określają stosunek osoby do innych osób, do społeczności, określają osobę jako byt społeczny. (Podsiad, Więckowski, 1983: 260)

Wobec wyróżnienia w bycie dwóch jego porządków mówiących o istocie i istnieniu bytu zachodzi pytanie o zależność tychże odnośnie do wskazanego ducha i materii, jako elementów istnienia osoby. Jak się wydaje, kluczową kwestię dotyczącą osoby stanowi zagadnienie złożenia duchowo-materialnego, który tworzy dychotomiczny obraz jednostki ludzkiej. Człowiek jest jednością duszy i ciała, żadnemu z tych elementów nie można oddzielnie przypisać w sposób 
adekwatny bycia człowiekiem oraz kondycji osoby. Podkreśla to Tomasz Duma, pisząc, że: „Związek duszy z ciałem jest konieczny, gdyż oba te czynniki tworzą substancję ludzką, co znaczy, że ani sama dusza, ani samo ciało nie mogą być człowiekiem” (Duma, 2013: 19). Relacja duszy i ciała posiada określone rozumienie, ze względu na pierwotne założenie dokonujące rozróżnienia na istotę $\mathrm{i}$ istnienie, potencję $\mathrm{i}$ akt oraz formę i materię. Kwestia ta ma charakter złożony, gdyż obydwa elementy są niezbędne w konstytuowaniu bytu ludzkiego, jednak zarazem są niesymetryczne względem siebie co do ontologicznej ważności w konstytuowaniu bytu ludzkiego. Jerzy Buxakowski, odnosząc się do kwestii pierwszej, stwierdza, iż: „jest dogmatem, że jednostkowa i nieśmiertelna dusza jest formą substancjalną ciała ludzkiego" (Buxakowski, 1998: 255). Współczesna interpretacja ujmuje człowieka jako byt jednostkowy, którego elementami konstytuującymi są dusza i ciało. Z tego względu podkreśla się, że: „człowiek nie tyle «posiada» duszę i ciało, lecz jest duszą i ciałem” (Kowalczyk, 2007: 233). W ujęciu bardziej szczegółowym, zaproponowanym przez Mieczysława Gogacza, dusza, współkonstytuując istnienie człowieka, przejawia się jako wola i intelekt. Wola jest podmiotem dla czynności decyzyjnych, zaś intelekt dla czynności poznawczych; natomiast ciało, współkonstytuując istnienie człowieka, posiada zespół władz zewnętrznych i wewnętrznych oraz przejawia aktywność na bodźce zwaną uczuciami (Gogacz, 1992: 15).

Wobec powyższego mamy tutaj wyraźne zaakcentowanie konieczności występowania obydwu elementów oraz wzajemnej niezbywalności każdego z osobna w konstytuowaniu bytu ludzkiego. Niemniej, jak już wspomniano, obok zagadnienia o równorzędności obydwu elementów tworzących człowieka możemy mówić o ich radykalnej niewspółmierności, co wiąże się ostatecznie z duchową naturą bytu ludzkiego. Jak łatwo zauważyć, zagadnienie pierwsze odnosi się do problemu istnienia człowieka w ogóle, czyli formalnych warunków jego zaistnienia, i wskazuje, że skoro obydwa są niezbędne, to $\mathrm{z}$ tego względu są równie ważne, natomiast niewspółmierność dotyczy bardziej roli bądź znaczenia „udzielania się w istnieniu". Kategoria osoby ma złożoną strukturę bytową o układzie hierarchicznym. Przede wszystkim kwestia ta jawi się jako zadanie określenia podstawy podmiotu ludzkiego, wskazania podłoża dla świadomości, czyli „Ja” człowieka. Wobec tego należy się przyjrzeć ogólnemu podziałowi bytów, na jakie wskazuje tradycyjna ontologia. Za Michałem Hempolińskim możemy wyróżnić następujące rodzaje bytów oraz przysługujące im cechy (Hempoliński, 1994: 14): a) byt materialny - przestrzenny i czasowy; b) byt psychiczny i świadomościowy - czasowy, nieprzestrzenny i niefizyczny; c) byt idealny - nieprzestrzenny, niefizyczny, nieczasowy, nieduchowy, ogólny, będący czystą formą; d) byt duchowy rozumiany jako substancjalny, nieprzestrzenny i niefizyczny podmiot dla stanów świadomości i stanów psychicznych oraz nie dający się zredukować do tych sta- 
nów. Pomijając rodzaj bytu typu trzeciego (c), czyli bytu idealnego, w przypadku pedagogiki chrześcijańskiej pozostałe rodzaje bytów mają swoje zastosowanie, ponieważ dotyczą człowieka w jego różnych aspektach. Oczywiście współczesne odmiany materializmu nie podzielają takiego podziału, negując byt duchowy, wskazują, iż życie psychiczne ma swoją genezę w materii. Według tych poglądów człowiek jest zbudowany z uorganizowanej wielostopniowo materii i w zależności od stopnia jej złożoności ma możliwość realizacji określonych funkcji (Duma, 2013: 13). Zasadniczą kwestią sporną jest problem lokalizacji życia psychicznego podmiotu ludzkiego i przysługujących mu najważniejszych aktów. Pogląd chrześcijański wskazuje na to, że u podstaw tożsamości działania człowieka jest jedna konieczna podstawa bytowa. Potwierdza to samoświadomość podmiotu ludzkiego, świadomość własnej jaźni. Podstawa ta nie może być ulokowana na poziomie bytu psychicznego, ponieważ nie można by było mówić o transcendencji aktów poznawczych, aktów woli oraz transcendencji „Ja”, gdyż nie wykraczałyby one poza funkcje naturalne jako pochodne czynności fizjologicznych. $Z$ tego względu, jak pisze T. Duma, „jaźń musi być zapodmiotowana bezpośrednio w duszy, co wskazuje $\mathrm{z}$ kolei na fakt, iż dusza musi istnieć w sobie i być podmiotem na sposób niezależny od ciała, ujawniając w ten sposób swoją substancjalną naturę" (Duma, 2013: 15). Substancjalność odnosi się do bytu duchowego i wskazuje na to, co trwałe i niezmienne, istniejące samoistnie i niezależnie (Kosior, 1996: 447). Jak łatwo zauważyć, podane jak dotąd wyszczególnienia odnoszą się do różnych poziomów struktury bytowej człowieka, które ostatecznie mają na celu jakieś najwyższe dobro, które przekracza wymiar doczesny i stanowi ostateczne spełnienie się osoby ludzkiej. Oczywiście, byt duchowy musi być bytem prostym, inaczej mogłaby w nim zachodzić możliwość zmiany i tym samym czasowość, a zarazem możliwość zmiany do jakiejś bardziej pierwotnej formy bytu. W stosunku do cech wymienionych szczególne znaczenie ma kwestia złączenia tego, co duchowe, z materią. Dotyczy to cechy niepowtarzalności, która w kontekście kategorii osoby ma dwa aspekty: egzystencjalny i esencjalny. Charakterystyka osoby nie może się obyć bez tego rozróżnienia, gdyż w rzeczy samej aspekty te nawiązują do substancjalności osoby, akcentując szczególnie właśnie jej jedyność i niepowtarzalność, czy też nieudzielalność, jak określa to John F. Crosby. Pierwszy z wymienionych aspektów wskazuje, że każdy z ludzi, mimo przynależności gatunkowej, ma pewną swoistość i jedyność, która nie może być w żaden sposób zastąpiona i powielona. Wspomniany autor stwierdza, iż:

Tego, czym osoba jest, nie można w sposób właściwy ująć w oderwaniu od nieudzielalnego bycia sobą każdej osoby. Naturalnie, żadnego konkretnego bytu nie można adekwatnie ująć bez jego nieudzielalnego bycia sobą (...), ponieważ w oderwaniu od nieudzielalnego bycia sobą ów byt jest niczym. (Crosby, 2007: 76) 
Charakterystyka ta pragnie przekroczyć pewną przypadkowość zorganizowanej materii w jakiś swoisty kształt oraz oddać określoną konkretność i swoisty ciężar istnienia osoby, w której materialne czynniki uczestniczą w byciu osobowym. Z kolei aspekt esencjalny akcentuje jedyność istnienia osoby w ogóle, bowiem nie ma „drugiej takiej” pod każdym względem, jaki da się skategoryzować. Ujawnia się tutaj niepowtarzalność w sensie metafizycznym, czyli dotyczy bardziej podmiotu duchowego o cechach substancji. Aspekt ten mówi o człowieczeństwie w sensie ogólnym, które nie zatraca się w powszechności, jakiejś uniwersalności, idei człowieczeństwa, lecz nadal akcentuje jedyność w swoim rodzaju jednostki ludzkiej, mimo swej przynależności gatunkowej. J.F. Crosby, charakteryzując ten aspekt, opisuje go w trzech punktach:

- Każda istota ludzka posiada swoje własne człowieczeństwo, które nie ma charakteru uniwersalnego i nie znika w ogólnej idei człowieczeństwa, bowiem $\mathrm{w}$ wymiarze istotowym każdy byt jest $\mathrm{w}$ pewnym sensie czymś własnym dla siebie.

-W drugim punkcie autor nawiązuje do specyficznego doświadczenia jedyności osoby niejako już na sposób pozafenomenalny i w zredukowaniu tego, co powszechne w człowieku, np. dla kochającego mężczyzny kobiecość kobiety jawi się jako ,jedyna taka kobieta”.

- Trzeci aspekt dotyczy „esencjalnej treści”, która jest całkowicie w posiadaniu przez tę, a nie inną osobę w taki sposób, iż inna osoba nie może w niej uczestniczyć, co oznacza, jak sugeruje autor, stawiając otwarte pytanie, czy każda istota ludzka nie może istnieć na swój własny sposób, nie tyle uczestnicząc w gatunku, lecz jako pewien „podgatunek ludzkości” (Crosby, 2007: 78-79).

Autor, konkludując swoje rozważania na temat niepowtarzalności osoby w tym aspekcie, choć tyczy się to także aspektu egzystencjalnego, pisze sugestywnie, że:

Każda osoba posiada coś esencjalnego, coś, co tylko ona może posiadać lub raczej czym może być (...), co świat na zawsze by stracił, co pozostawiłoby w nim nieodwracalną metafizyczną wyrwę, gdyby osoba to ucieleśniająca miała zupełnie przestać istnieć. (Crosby, 2007: 80)

Analizy te ujawniają wartość każdej osoby i jej istnienia jako niezbędnego zarówno $\mathrm{w}$ wymiarze ogólnoludzkim, jak i dla całego uniwersum. Z perspektywy ontologicznej jeśli mówimy o istnieniu, to odnosi się to przede wszystkim do duszy, natomiast ciału z tego względu przysługuje istnienie wtórne, oczywiście nie w sensie jakiegoś następstwa czasowego. Mieczysław Albert Krąpiec charakteryzuje tę kwestię w następujący sposób:

Istnienie (...) bytowe jest związane z duszą bezpośrednio; znaczy to, że akt istnienia aktualizuje w porządku bytowym duszę, która samo istniejąc, organizuje sobie (formuje) ciało potrzeb- 
ne jej do tego, by mogła działać, by mogła się wyrazić i dojść do pełnego rozwoju, używając swoich władz działania. Dla ciała istnieć znaczy być organizowanym; moment dezorganizacji ciała jest momentem zaprzestania istnienia ciała ludzkiego i powrotu do stanu materii nieludzkiej. (Krąpiec, 1991: 139)

Z tego względu chrześcijańska edukacja religijna ma na uwadze istnienie, ale w swym szerokim aspekcie, które opiera się na religijnym postrzeganiu istnienia, wykraczającym poza doczesność i z tej oto perspektywy dopiero wartościuje życie ziemskie człowieka. Stąd też nacisk i szczególna troska o ostateczne istnienie, co odzwierciedla się w treści przekazu zawartego w edukacji religijnej w chrześcijaństwie. W głównej mierze przesądza o tym położenie akcentu na substancjalność osoby, czyli byt duchowy w strukturze ontycznej człowieka, a także "presja” na taki sposób postępowania za życia, który ma na uwadze spełnienie się istoty ludzkiej w wymiarze eschatologicznym. Jest tak ze względu na kwestię przewagi uczestniczenia $\mathrm{w}$ konstytuowaniu bytu ludzkiego przez aspekt duchowy. Odzwierciedla on się w tym, że dusza jest formą substancjalną ciała, kształtuje je i udziela mu istnienia. Za M.A. Krąpcem możemy zauważyć, iż:

Jest (...) tylko jedno istnienie człowieka, ale istnienie to człowiek posiada nie dlatego, że jest ono wynikiem i następstwem organizacji materialnej, ale dlatego, że jest przynależne duszy, która na mocy przysługującego sobie istnienia: będąc samoistną, jest także i formą ciała, któremu udziela swojego istnienia. (Krąpiec, 1991: 137)

Antropologia chrześcijańska wyraźnie wskazuje na poziom duchowy, na substancjalny i duchowy podmiot. Oczywiście, z tej perspektywy celem zabiegów pedagogicznych jest człowiek jako istota duchowo-materialna, ale przede wszystkim pragnie oddziaływać na to, co duchowe i ostatecznie przekraczające wymiar materialny i doczesny. Dzięki temu powstaje swoiste napięcie, które ujawnia się w podejściu do edukacji religijnej. Jest to punkt widzenia akcentujący konsekwencje aktywności ziemskiej prowadzące do adekwatnego zadośćuczynienia za moralne lub niemoralne życie. Bliższa analiza ukazuje, w gruncie rzeczy, podstawę nie tylko założeń dla edukacji chrześcijańskiej, ale każdej edukacji religijnej. Jest nim odniesienie do substancjalnego podmiotu duchowego, które wykracza poza to, co empiryczne, oraz poza doczesność. To przedmiot refleksji eschatologicznej doktryny religijnej, którego podstawowym przesłaniem jest wskazanie na konsekwencje aktywności ziemskiej jednostki. Wynika z tego troska o właściwe ukształtowanie człowieka, które w tej perspektywie jest postrzegane jako dobro dla niego samego będące zwieńczeniem życia doczesnego. Kluczowa kwestia dotyczy należytego wartościowania życia człowieka, czym jest i dokąd zmierza, czyli jakie jest jego eschatologiczne przeznaczenie. W myśl poglądów chrześci- 
jańskich człowiek jest w stanie separacji z Bogiem, zaś życie doczesne jest elementem drogi powrotu do Boga i zjednoczenia z Nim. Cel soteriologiczny jest głównym motywem przekazu zawartym $\mathrm{w}$ doktrynie, stąd też edukacja religijna i wszelki wysiłek wychowawczy jest nakierowany na ów cel. Barbara Kiereś, rozważając to zagadnienie, przedstawia w syntetyczny sposób cele i środki pedagogiczne z perspektywy założeń religii chrześcijańskiej. Wspomniana autorka wskazuje, że

istotnymi cechami wyróżniającymi wychowanie w kulturze chrześcijańskiej są: uznanie bezwzględnie ostatecznego celu życia, którym jest osiągnięcie pełni doskonałości w bezpośrednim zjednoczeniu z Bogiem, swoista dla chrześcijan droga do celu - naśladowanie Chrystusa i usprawnianie się w dobrych uczynkach, a szczególnie w czynnej miłości Boga, siebie samego i bliźniego w Bogu oraz swoiste dla chrześcijaństwa środki wychowawcze, takie jak liturgia i sakramenty obok wspólnych dla wszystkich ludzi środków wychowawczych opartych na naturze ludzkiej. (Kiereś, 2007: 99)

Możemy powiedzieć za Jerzym Bagrowiczem w ujęciu bardziej szczegółowym, iż celem zabiegów pedagogicznych z perspektywy chrześcijańskiej jest formacja ludzkiej osoby, czyli taki rodzaj oddziaływania, w którym człowiek dojrzewa osobowo, staje się coraz bardziej osobą, realizując przy tym cele i właściwości społecznie pożądane (Bagrowicz, 2008: 356-357). Autor ten zauważa również, że proces stawania się osobą zachodzi wtedy, gdy człowiek dąży do dobra, prawdy i piękna, pragnie urzeczywistnić te wartości i zastosować w życiu, dokonując wyboru od wartości materialnych poprzez wartości duchowe do wartości absolutnych. Stąd zabiegi pedagogiczne zmierzają do „wzbudzenia osoby” w człowieku (Bagrowicz, 2008: 359), czyli, w rzeczy samej, odkrycia jego własnej tożsamości. To dążenie do ukształtowania dojrzałej osobowości, u podstaw której istnieje formacja sumienia, gdyż jak pisze w innym miejscu wspomniany autor - „W nim to doświadcza się najbardziej osobowego wymiaru wychowania i urzeczywistnienia swojego człowieczeństwa" (Bagrowicz, 2008: 364). Ponadto, podług religii chrześcijańskiej, sumienie jest napominającym głosem Boga w człowieku, przez co jawi się jako niezbędny element w chrześcijańskiej soteriologii. Tadeusz Ślipko, dokonując precyzyjnej charakterystyki sumienia, wskazuje, że

jest to w świetle ogólnej oceny lub normy uformowany osąd o moralnym dobru/złu zamierzonego przez człowieka jego własnego konkretnego aktu, którego zrealizowanie staje się dlań źródłem wewnętrznej aprobaty bądź poczucia winy, własnego bycia dobrym lub złym człowiekiem. (Ślipko, 2004: 377)

Ów sąd sumienia to akt poznawczy mający charakter normatywny jako przesłanka do określonego postępowania. Formacja sumienia ma w domyśle na uwa- 
dze także drugą kwestię, która wskazuje, żeby pojawiające się akty poznawcze i w konsekwencji sądy były egzekwowane, czyli, z jednej strony były obdarzone mocą jednoznaczności, a z drugiej, aktywizowały wolę do ich spełniania. Kwestia realizacji przesłanek sumienia, czyli zgodności woli z powinnością wyrażaną przez sąd sumienia, tworzy przyczyny do zasługiwania w sensie eschatologicznym, a wobec zagadnień tu rozważanych stanowi także przedmiot chrześcijańskiej myśli pedagogicznej.

Kluczowe z perspektywy ontologicznej jest to, że struktura bytowa człowieka nie tylko kieruje ku transcendencji, akcentując dobro duszy, lecz również to, w jaki sposób formułuje i wartościuje życie doczesne. Swoista ważność doczesności opiera się na tym, iż konsekwencje moralne życia według poglądów chrześcijańskich są ostatecznie tylko dwojakiego rodzaju - stan zbawienia i pełnia szczęścia albo stan potępienia, czyli ostateczna zagłada osoby - wieczne cierpienie bądź anihilacja. Przyjęcie eschatologicznej perspektywy w konsekwencji powoduje właśnie silne wartościowanie sytuacji doczesnej człowieka, która dokonuje oceny wszelkiej aktywności moralnej człowieka ze względu na jego pozytywne lub negatywne skutki po biologicznej śmierci. Zatem troska o człowieka przyjmuje perspektywę eschatologiczną, czyli troski o dalsze jego losy po biologicznej śmierci, która wynika bezpośrednio z przyjętych założeń ontologicznych. Ten cel przyświeca również wszelkiej narracji pedagogicznej związanej z religią i wnikającego z niej oddziaływania. $Z$ tego właśnie względu bardzo ważna jest formacja sumienia i uwrażliwienie na dobro drugiego człowieka w myśl normatywnych zaleceń ewangelicznych miłości bliźniego. Zdarzenia życia są rozpatrywane z perspektywy eschatologicznej, czyli pod kątem ich pozagrobowych skutków. Zatem wszelka aktywność ludzka ma przede wszystkim na uwadze cel soteriologiczny, stąd też źródłowo wszelkie czynności pedagogiczne przybierają w sposób naturalny taki charakter, mając na uwadze realizację tegoż celu. Wobec tego rodzaju dążenia do realizacji normatywów danego systemu religijnego możemy mówić o szczególnym typie chrześcijańskiej edukacji religijnej, mianowicie o edukacji katechetyczno-ewangelizacyjnej, nazywanej także katechetyczno-konfesyjną lub separacyjną (Mąkosa, 2011: 125). Korzystając z rozróżnienia Pawła Mąkosy, należy stwierdzić, że $\mathrm{w}$ tym przypadku położonon większy nacisk na realizację funkcji eklezjalnej, czyli funkcji katechezy (nauczająca, wychowawcza, wtajemniczająca), niż funkcji szkoły (dydaktyczna, wychowawcza, opiekuńcza). Autor nieco dalej ujawnia, że typ ten koncentruje się na przekazie depozytu wiary, zasad moralnych, elementów kultu oraz zawiera wskazanie na przyjęcie tych treści i stosowanie ich w życiu. Z tego względu katecheta nie tyle jest nauczającym religii, co głosicielem orędzia zbawienia (Mąkosa, 2011: 125-126). Wspomniany autor zauważa także, iż ten typ edukacji religijnej wysuwa na pierwszy plan swój 
cel soteriologiczny i zmierza w swym przekazie do wypełnienia wiary chrześcijańskiej, czyli do osobowego zjednoczenia z Bogiem, opierając się przy tym na Piśmie Świętym, liturgii i nauczaniu Kościoła (Mąkosa, 2011: 126). Jednak sprawą zasadniczą dla edukacji religijnej jest to, że powinna ona również sprostać wyzwaniom, jakie niesie ze sobą współczesność. Jarosław Michalski, odnosząc się do tego zagadnienia, pisze:

Edukacja religijna, będąc częścią całego procesu edukacji człowieka, nie pozostaje w oderwaniu od konkretnych uwarunkowań społeczno-kulturowych, których cechą charakterystyczną jest obecnie postmodernizm ze swoim relatywizmem i kategorią wielości. (Michalski, 2013: 199)

Edukacja konfesyjna w ujęciu katechetyczno-ewangelizacyjnym jest zatem konsekwencją określonej antropologii i spełnia przesłanki danego wyznania. Jednak ten typ edukacji religijnej napotyka na trudności ze względu na swoją nieadekwatność, gdyż wobec zachodzących współcześnie przemian $\mathrm{w}$ różnych sferach praktyki życiowej oraz dla osób niewierzących i wątpiących obecna w nim funkcja wtajemniczająca jest niezrozumiała i przedwczesna (Mąkosa, 2011: 127). Ograniczenia, które z tego wynikają, wymuszają zastosowanie innych kryteriów, które prowadzą do swego rodzaju kompromisu, pozwalając na zachowanie równowagi między wymogami szkoły świeckiej a wyznaniową treścią przekazu. Warunki te spełnia inny typ chrześcijańskiej edukacji religijnej, mianowicie w ujęciu informacyjno-wychowawczym. P. Mąkosa zauważa, iż ujęcie to jest nakierowane na realizację zarówno celów eklezjalnych, jak i szkolnych zarazem, bez popadania w skrajności. Wspomniany autor pisze:

Propagowane jest ono przez zwolenników dialogu pedagogiczno-teologicznego, który z jednej strony ma stać na straży własnej tożsamości wyznaniowej, z drugiej zaś uwzględniać współczesne przemiany kulturowe i kosmopolityczne nierzadko nastawienie uczestnika lekcji religii. (Mąkosa, 2011: 127)

Zatem konkretne działania na polu pedagogiki chrześcijańskiej muszą z konieczności uwzględniać czasy współczesne, gdyż mimo zamysłu określonego przekazu i oddziaływania mogą być niezrozumiałe i przedwczesne w odbiorze. Wraz z różnicowaniem się społeczeństwa na tle religijnym i odchodzeniem od religijności typu instytucjonalnego rośnie zapotrzebowanie na przestrzeń do wolnego dyskursu. Konsekwencją tego trendu jest brak akceptacji w szkole publicznej dla modelu katechetyczno-ewagelizacyjnego w edukacji religijnej, który nie tyle ma na uwadze sam przekaz informacji religijnej, co przede wszystkim troszczy się o ostateczne losy człowieka, zgodnie zresztą z tym, jaką zakłada antropologię. 
Należy dodać do powyższego, że oczywistym błędem byłaby marginalizacja roli edukacji religijnej, czy też umniejszanie jej znaczenia w myśl jakichś tendencji redukcyjnych na tle światopoglądowym, jako wiedzy rzekomej lub niepełnowartościowej wobec innych przedmiotów programu szkolnego. Beata A. Orłowska wskazuje, że wychowanie religijne jest niezbędne ze względu na wymogi, jakie stawia współczesność. Autorka odnosi się przy tym do szerszego zagadnienia, jakim jest współczesna edukacja międzykulturowa i wynikająca $\mathrm{z}$ tego konieczność dialogu z przedstawicielami innych kultur (Orłowska, 2012: 133). Szczególnie dotyczy to wartości religijnych, gdyż stanowią one niezbywalny element kształtujący światopogląd człowieka jako punkt odniesienia do zachodzących zdarzeń, swoisty rdzeń, podług którego „ogląda się” i ocenia się świat. Autorka, mając na uwadze potrzebę edukacji religijnej $\mathrm{w}$ procesie nauczania, wskazuje w innym miejscu, iż „współczesna szkoła musi brać pod uwagę również wymiar religijny człowieka" (Orłowska, 2012: 134).

W podsumowaniu niniejszych rozważań należy stwierdzić, że założenia doktrynalne chrześcijaństwa, płynąca zeń antropologia, odzwierciedlają się w chrześcijańskiej pedagogice oraz stosowanych środkach pedagogicznych. Chrześcijańska edukacja religijna odwołuje się do personalizmu i humanizmu chrześcijańskiego. Rozumową podstawę dla pedagogiki chrześcijańskiej stanowi filozofia realizmu arystotelesowskiego i tomistycznego $\mathrm{z}$ akcentem położonym na tę drugą. Konsekwencją jest realistyczna teoria poznania świata obiektywnego za sprawą wrażeń zmysłowych i abstrahowania, czyli odkrywania cech istotnych dla tworzenia pojęć. Antropologia chrześcijańska wskazuje, że człowiek jest bytem osobowym, stąd też punktem wyjścia jest kategoria osoby. To jednostkowy, substancjalny, cielesno-duchowy podmiot, któremu przysługuje wrodzona godność i wolność. Aspekt duchowy, czyli dusza, jest formą substancjalną ciała, która udziela mu istnienia, kształtując je. Ważność duszy, jej samoistność i nieśmiertelność powoduje, że cel wszelkich wysiłków pedagogicznych w chrześcijaństwie skupia się na formacji sumienia oraz doprowadzeniu do uczestniczenia w liturgii Kościoła. Celem jest ukształtowanie wartości chrześcijańskich, ich przejawianie w życiu codziennym oraz spełnianie sakramentów. Taki punkt widzenia jest charakterystyczny dla konfesyjnej edukacji religijnej w ujęciu katechetyczno-ewangelizacyjnym. Przyjmuje ona eschatologiczny punkt widzenia, postrzega życie ziemskie jako drogę, jako czas aktywności, który znajdzie swoje adekwatne zadośćuczynienie po biologicznej śmierci. Określona koncepcja człowieka przesądza o zastosowanych środkach pedagogicznych, czyli sposobie podejścia do wychowanka. Charakterystyka osoby wskazuje, że celem wysiłków człowieka jest jego zbawienie, czyli osiągnięcie komunii z Bogiem, stąd pedagogika religijna, jej konkretny przekaz, ma swoje ugruntowanie w soteriologii. Niemniej panujący obecnie plu- 
ralizm i wielokulturowość, a także określone warunki, jakie stawia szkoła publiczna, wymuszają zastosowanie takiego typu edukacji religijnej, która będzie spełniała ontologiczne przesłanki antropologii chrześcijańskiej a zarazem uwzględniała wymogi współczesności. Taki charakter ma edukacja religijna w ujęciu informacyjno-wychowawczym, która stara się już wskazywać na wielość dróg prowadzących do zbawienia, a przynajmniej nie powinna faworyzować jednej. Jednak powoduje to, że przekaz, choć, $z$ jednej strony uwzględnia strukturę ontyczną osoby, jednak z drugiej - rezygnuje już z środków, które mają na uwadze cel soteriologiczny. Należy stwierdzić, że struktura ontyczna istoty ludzkiej jako osoby warunkuje charakter narracji w edukacji religijnej. To co stoi u podstaw danej edukacji religijnej, to antropologia, która suponuje określony typ tejże edukacji. Jednakże skoro treść przekazu ulega zmianie to nie odzwierciedla tego, co sama pierwotnie zakłada, stąd też w rzeczy samej ma już na uwadze także inną ontologię.

\section{Literatura}

Bagrowicz J. (2008). Wychowanie personalistyczne w chrześcijaństwie. [W:] M. Rusiecki (red.). Personalizm polski. Lublin.

Bagrowicz J. (2010). Dialog w edukacji religijnej. „Paedagogia Christiana” nr 2/26.

Bremer J. (2008). Osoba - fikcja czy rzeczywistość? Kraków.

Buxakowski J. (1998). Stwórca i stworzenie. Teologia prawd wiary. T. IV. Pelplin.

Buxakowski J. (2001). Wieczność i człowiek. Eschatologia. Pelpin.

Crosby J.F. (2007). Zarys filozofii osoby. Kraków.

Duma T. (2013). U podstaw tożsamości osobowej człowieka. „Fides et Ratio” nr 4(16).

Gogacz M. (1993). Podstawy wychowania. Niepokalanów.

Granat W. (1985). Personalizm chrześcijański. Teologia osoby ludzkiej. Poznań.

Hempoliński M. (1994). Problematyka ontologii. [W:] M. Hempoliński (red.). Ontologia. Antologia tekstów filozoficznych. Wrocław-Warszawa-Kraków.

Kiereś B. (2007). Kultura chrześcijańska wobec postmodernistycznej ideologii „anty” w pedagogice. [W:] A. Rynio (red.). Wychowanie chrześcijańskie. Między tradycją a współczesnością. Lublin.

Kowalczyk M. (2007). Traktat o stworzeniu. [W:] E. Adamiak, A. Czaja, J. Majewski (red.). Dogmatyka. T. 6. Warszawa.

Krąpiec M.A. (1991). Dzieła. T. 9: Ja-człowiek. Lublin.

Kunowski S. (2004). Podstawy współczesnej pedagogiki. Warszawa.

Marek Z. (2013). Tożsamość pedagogiki religii. „Paedagogia Christiana” nr 1/31.

Michalski J. (2013) W kierunku nowego modelu wspótczesnej edukacji religijnej. „Paedagogia Christiana" nr $1 / 31$.

Milerski B. (2009). Edukacja religijna w szkole neutralnej światopoglądowo. http://ekumenia.pl/wpcontent/uploads/2014/03/Edukacja-religijna-w-szkole-neutralnej-swiatopogladowoB.Milerski.pdf (dostęp: 19.02.2015). 
Milerski B. (2009). Kształcenie międzykulturowe w szkole $z$ perspektywy pedagogiki religii. http://ekumenia.pl/wp-content/uploads/2014/03/Ksztalcenie-miedzykulturowe-w-szkole-zperspektywy-pedagogiki-religii-B.Milerski.pdf (dostęp: 19.02.2015).

Orłowska B.A. (2012). Edukacja religijna jako podstawa dialogu między kulturami. „Perspectiva. Legnickie Studia Teologiczno-Historyczne" nr 2(21).

Placha J. (2013). Tożsamość osobowa człowieka w ujęciu pedagogiki chrześcijańskiej. „Fides et Ratio" nr 4(16).

Podsiad A., Więckowski Z. (1983). Mały słownik terminów i pojęć filozoficznych. Warszawa.

Ślipko T. (2004) Zarys etyki ogólnej. Kraków.

Vorgrimler H. (2005) Nowy leksykon teologiczny. Warszawa.

Zarzecki L. (2012). Teoretyczne podstawy wychowania. Jelenia Góra.

\section{Ontological Bases of the Religious Education in Christianity}

\section{Summary}

The Christian religious education, that is otherwise the Christian pedagogics refers to the personalism and the Christian humanism. The rational base of the Christian pedagogics is based on the philosophy of the Aristotelian and Thomistic realism with an accent situated on the second. A consequence of this is the realistic epistemology of the objective world because of sense impressions and abstractions, which are explorations of essential features for the creation of concepts. Every pedagogic theory at base is determined by a specific anthropology. Christian anthropology indicates that the man is a personal entity, for that reason the start point of this reflection is the category of the person. It is an individual, substantial, bodily-spiritual subject to which is vested the inborn dignity and freedom. The spiritual aspect, that is the soul is a substantial form of the body, which founding his existence and shaping it. The importance of the soul, her independence and the immortality causes that for purposes of pedagogic efforts it concentrate on a formation of the conscience and bringing to the sacramental life. In accordance with confessional and catechumenal Christian religious education has the space of the pedagogic influence consists of important elements like the school and the Church. However confessional religious educations significantly differ between themselves, because they realize in different manner ecclesial functions, i.e. functions of the catechesis (teaching, educational and initiatory) and functions of the school (didactic, educational, protective). The configuration of Christian values is a goal for a man which allows follow Christ in the daily life and the bringing to the realization of sacraments. This type of confessional Christian education accepts an eschatological point of view which perceives the earthly life as the way, the time of the activity that will find his adequate satisfaction post mortem. However, the other type of religious education, the confessional but dialogical and non-catechumenal Christian religious education also indicates the spiritual dimension, but the its eschatology has only an informational character due to the public nature of the school and the pluralism of religions in nowadays. In consideration of this we can say that there are plurality of ways, or cannot favor one at least. The article has in mind to points out ontological basics which are at the ground of the religious education in Christianity. Specific conception of a man is behind in every pedagog- 
ics theory so it decides applied pedagogic measures and way of the approach to the pupil. The characteristics of the person indicates that the sense of life for the man is his salvation after death, that is the achievement of Communion with God, for that reason the religious pedagogics narration is finally based on soteriology, that is why the Christian religious education is confessional. However bearing in mind conditions of modern times, it enforce using a such type of the religious education which on one hand will fulfill ontological premises of Christian anthropology and at the same time, on the other hand, will take into account requirements of the present day. It's causing that the dialogical and non-catechumenal Christian religious education, one can admit, respects the ontological structure of a man, but, due the circumstances also throws up soteriological measures and any activity being tied with the cult. 